\title{
CAN TROIDES HELENA AND PACHLIOPTA ADAMAS CO-EXIST? A PERSPECTIVE FROM THE BUTTERFLY BREEDING FACILITY, CIBINONG SCIENCE CENTER, INDONESIA
}

\author{
Djunijanti Peggie $^{* 1}$, Supadi ${ }^{2}$, Guntoro $^{2}$, and Muhammad Rasyidi ${ }^{2}$ \\ ${ }^{1}$ Museum Zoologicum Bogoriense, Research Center for Biology, National Research \\ and Innovation Agency, Jl. Raya Jakarta-Bogor Km. 46, Cibinong, Bogor 16911, Indonesia \\ ${ }^{2}$ Temporary assistant at Museum Zoologicum Bogoriense, Research Center for Biology, National Research and \\ Innovation Agency, Jl. Raya Jakarta-Bogor Km. 46, Cibinong, Bogor 16911, Indonesia \\ *Corresponding author: kupu2indonesia@gmail.com; peggie94@yahoo.com
}

Received: 22 November 2021; Accepted: 14 December 2021; Published: 30 December 2021

\begin{abstract}
Troides helena and Pachliopta adamas utilize the same food plant species: Aristolochia acuminata. For the purpose of captive breeding and conservation, it is desirable to find out whether they can co-exist in captivity. Captive breeding research was conducted on the butterfly species within the period of October 2016 to September 2019. In total, 1,361 individuals were observed. Data on adult emergence of the species is presented to show the trends. Both species co-existed poorly at the facility when food plants were limited. It took 45.9 days for $T$. helena helena and 32.6 days for $P$. adamas adamas to grow from egg to imago stage. Habitat enrichment can encourage the species to come and establish the population.
\end{abstract}

Key words: captive breeding, co-exist, Pachliopta adamas, parental stocks, Troides helena

\section{INTRODUCTION}

Troides helena (Linnaeus, 1758) and Pachliopta adamas (Zinken, 1831) belong to the family of Papilionidae, the swallowtail butterflies. Troides helena is quite widely distributed across Sumatra, Kalimantan, Java, Bali, western part of Nusa Tenggara, Sulawesi, and also from northern India to Malaysia at 0-1000 m asl. (Endo \& Ueda, 2004). This species is the most common protected butterfly species in Indonesia (Peggie, 2011; KLHK, 2018). Pachliopta adamas was included in P. aristolochiae sensu lato until the separation was proposed (Page \& Treadaway, 1995). Pachliopta adamas occurs in Java including Bawean, Enggano, and Tanahjampea.

Both butterfly species inhabit forest areas where they are closely associated with the larval host plants, Aristolochia acuminata (previously known as A. tagala, see Yao, 2015) of family Aristolochiaceae (Igarashi \& Fukuda, 1997). Veenakumari \& Mohanraj (1994) reported Thottea tomentosa, also of Aristolochiaceae, as the sole larval food plant for the Andaman endemic Pachliopta rhodifer. In Java, T. tomentosa is utilized as the food plant by Losaria coon, another swallowtail butterfly (Tsukada \& Nishiyama, 1982; Igarashi \& Fukuda, 1997). 
The two butterfly species in question are attractive and enjoyed in butterfly gardens, and are also in high demand by collectors. Therefore, it is desirable to have butterflies produced from captive breeding operations. To have a sustainable captive breeding program, we need to know the host plants (New et al., 1995) and how the species thrive in captivity (Peggie, 2018).

We have had a butterfly captive breeding facility since August 2016 through the Biovillage program of Indonesian Institute of Sciences. With this facility, we have been able to breed about 25 butterfly species to understand the life history and the biological aspects of many Indonesian butterfly species. In this paper, we focus on the Javan local subspecies: $T$. helena helena and P. adamas adamas. We aim to answer the questions: (1) whether habitat enrichment can encourage these butterfly species to come into the area; (2) how well $T$. helena and P. adamas can co-exist at the facility; (3) how long is the duration of the life cycle of $T$. helena helena and of $P$. adamas adamas.

\section{MATERIALS AND METHODS}

\section{Study area}

The research was conducted at the butterfly captive breeding facility of Indonesian Institute of Sciences (now National Research and Innovation Agency), located at Cibinong Science Center, Cibinong, Bogor, Indonesia. The butterfly facility covered an area of $800 \mathrm{~m}^{2}$ which included a $10 \times 20 \mathrm{~m}^{2}$ butterfly aviary and a $4 \times 6 \mathrm{~m}^{2}$ rearing room, which were built in May - August 2016. The observations at the rearing room provide data on the early stages of $T$. helena helena and $P$. adamas adamas, and the observations at the butterfly aviary provide data on adult activities. The observations were conducted at ambient temperatures of $25-34^{\circ} \mathrm{C}$. Various plants have been grown inside and outside the aviary to support butterflies, including the larval host plants, the flower plants, and plants for shading. The planting of various plants was started in May and June 2016. In September 2019, two smaller aviaries 6x6 $\mathrm{m}^{2}$ were built to accommodate the need to protect the host plants and to facilitate the egg-laying observation. However, the facility was relocated in October 2020 to give way to the new building for biodiversity collections.

\section{Materials}

Parental stocks of T. helena helena and P. adamas adamas were individuals naturally came flying to the area.

\section{Methods}

We started the captive breeding butterfly facility in May 2016 and were planning to obtain the butterfly parental stocks when the food plants have grown well. Fortunately, both species came flying to the area in October 2016. Upon finding the parental stocks, we 
obtained the eggs or larvae on the leaves of the host plants, A. acuminata, planted in rows on the field across the rearing room. The eggs were collected into a petri dish and brought to the rearing room to be observed. Each larva was placed inside a plastic container with a mesh cover lid. Fresh leaves of the host plants were added daily and excreta were removed. Caterpillars were observed as they grew and molted into next instars, pupated, and emerged. All data were recorded in the data book.

When an adult butterfly emerged from the pupal case and the wings were fully expanded and dried, usually a few hours after emerging, the individual was marked using paint markers (Hagler \& Jackson, 2001; Peggie, 2019). The date of emergence and sex were noted on the data book. Male and female of both species can be distinguished easily because they are dimorphic. The newly-emerged butterflies of the day were released into the aviary. Observation was then started on the butterflies flying in the aviary. Mating individuals and egg-laying individuals were photographed whenever possible and the individual numbers were recorded. Then eggs were collected on the host plants. To know the life span of adults, searching for wings of dead butterflies was conducted as well as recording the activity of the butterflies.

\section{RESULTS}

The observations of $T$. helena helena and $P$. adamas adamas were conducted within the period of October 2016 through September 2019, with 1,361 individuals in total (Table 1). We observed as much as we could, but obviously the data for each individual was not complete throughout the life stage. Out of 1,361 individuals, there were 941 of T. helena helena and 420 of $P$. adamas adamas. Out of 941 individuals of T. helena helena, 700 reached the adult stage, thus the early stage survival rate was $74.39 \%$. Out of 420 individuals $P$. adamas adamas individuals, 348 reached the adult stage, with the survival rate of $82.86 \%$.

Table 1. Summary of the numbers of individuals observed during the captive breeding research

\begin{tabular}{|c|c|c|c|c|c|}
\hline Species observed & $\begin{array}{l}\text { Number of } \\
\text { individuals } \\
\text { emerged as } \\
\quad \text { male }\end{array}$ & $\begin{array}{l}\text { Number of } \\
\text { individuals } \\
\text { emerged as } \\
\text { female }\end{array}$ & $\begin{array}{l}\text { Number of } \\
\text { successful } \\
\text { individuals to } \\
\text { adulthood }\end{array}$ & $\begin{array}{c}\text { Number of failed } \\
\text { individuals during } \\
\text { pre-adult }\end{array}$ & Total \\
\hline $\begin{array}{l}\text { Troides helena } \\
\text { helena }\end{array}$ & 366 & 334 & 700 & 241 & 941 \\
\hline $\begin{array}{l}\text { Pachliopta } \\
\text { adamas adamas }\end{array}$ & 188 & 160 & 348 & 72 & 420 \\
\hline Total & 554 & 494 & 1,048 & 313 & 1,361 \\
\hline
\end{tabular}


At the beginning, there were some obstacles related to the condition of the rearing room that was obviously too hot with fiber roof. Other factors included the attack of parasitoids on preadult stages, the scarcity of host plants, and the failure at eclosion to imago.

(1) Habitat enrichment can encourage both butterfly species to come into the area

Individuals of both species came flying across the area and the females laid eggs on the host plants so we did not need to go elsewhere to obtain the parental stocks. Otherwise, a permit would need to be requested from the Indonesian Ministry of Environment and Forestry as $T$. helena is one of the protected species in Indonesia. Larvae of $P$. adamas adamas were first observed on the leaves of $A$. acuminata on October 11, 2016. The females must have come to the area about 1-2 weeks prior to the date. As with T. helena helena, adults were first seen flying across the planting area on October 21, 2016, and later that afternoon and several days after that we found eggs for the parental stocks to start a new generation.

(2) How well T. helena helena and P. adamas adamas can co-exist at the facility?

At the time of observation, between October 2016 and September 2019, there were many butterfly species bred in the facility. We observed how well T. helena helena and $P$. adamas adamas could co-exist. The result of our observation (Fig. 1) showed that when $T$. helena helena was on the rise in January 2017, P. adamas adamas declined, and vice versa in June 2017 and January 2019. However, in March 2017 they seemed to co-exist quite well. The availability of sufficient host plants might be the issue in this case.

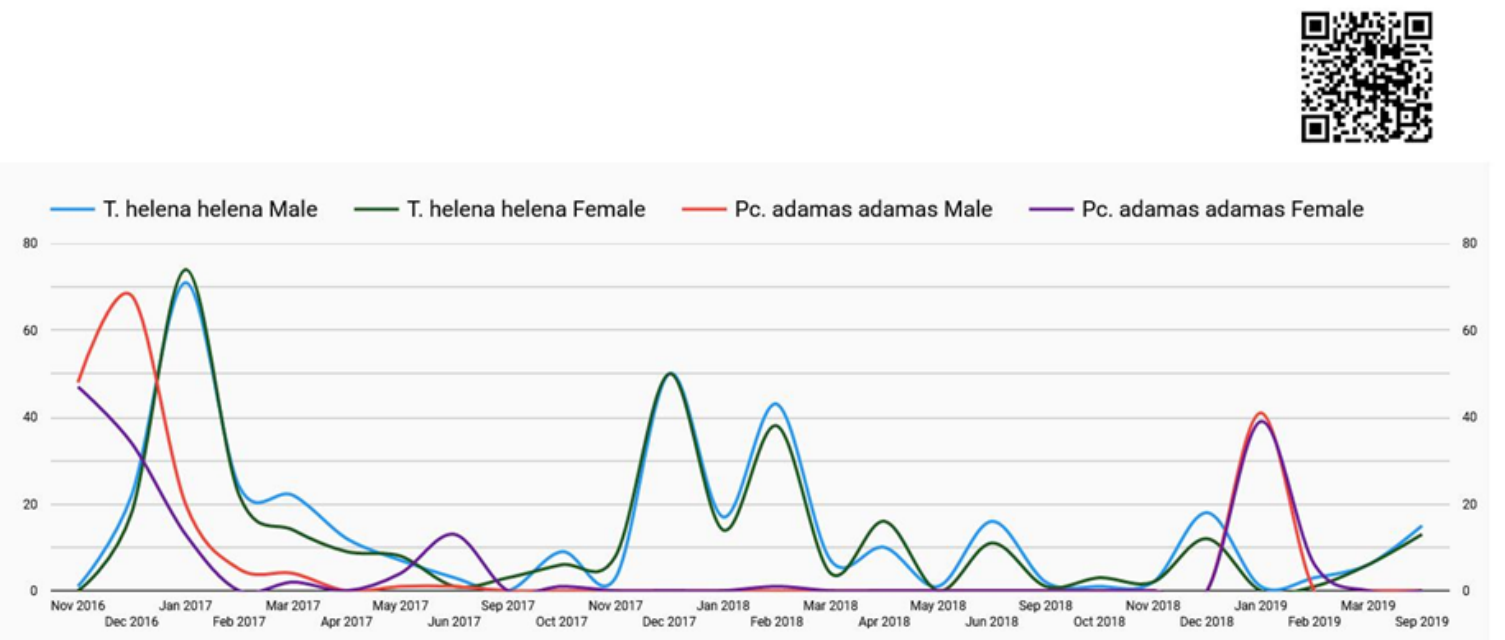

Figure 1. Adult emergence of $P$. adamas adamas and $T$. helena helena at the butterfly captive breeding facility between November 2016 and September 2019. 
(3) The duration of the life cycle of T. helena helena and of $P$. adamas adamas

Based on daily observations of $T$. helena helena, data of 71 individuals which had complete records of each stage (Fig. 2, Table 2) showed that eggs hatch about 5-6 days after being laid. The duration of each instar for early instar larvae (L1, L2, and L3) varied between 2-4 days, with one individual (\#2968) spent 5 days as L3. The duration of fourth instar larva (L4) varied between 3-5 days, with two individuals (\#2779 and \#2780) spent 6 days as L4. The duration of late instar larva (L5) varied between 3-12 days with an average of 8.2 days. The average duration spent as larvae was 20.8 days. The pupation process from prepupal to pupal stage lasts for one day. Pupal development lasts on average 18.6 days, with one individual (\#2440) spent only 15 days and one individual (\#2864) needed 22 days to eclosion. Therefore, the average duration from eggs to adults was 45.9 days. Observations in the aviary showed that many adults could live over 2 weeks and some individuals were recorded still alive for 21 days, but some lived only about a week.

Data of 12 individuals of $P$. adamas adamas which had complete records of each stage (Table 3) showed that the eggs hatch after 5 days. The larval stage consists of 5 instars. The duration of each instar for early instar larvae was on average 2 days, L4 varied between 2-3 days, and L5 varied between 4-5 days with one individual (\#628) spent 2 days only as L5. The average duration spent as larvae was 12.2 days. The process from prepupal to pupal stage lasts for one day. Pupal development lasts about 14.4 days. Therefore, the average duration from eggs to adults is 32.6 days. Observations of adult longevity were conducted on other available individuals, not only on 12 individuals with complete data. Some adults could live over 2 weeks and some individuals were recorded still alive for 25 days.

Figure 2. QR code for access to the full data of T. helena helena life span.

Observations on adult butterflies (Table 4) showed that males did not mate on the first day of emergence. Some females, on the other hand, were approached by males when they had just eclosed. Some females were observed mating on day 2 and day 3 after emergence (Figs 3a, 3b). The ovipositing females fluttered around the host plant several times before laying eggs on the underside of leaves or on the bark (Fig. 3c). Some females were observed also visiting flowers in-between ovipositing activity. The smaller aviary was built later to enable the observation of egg laying behavior. However, when it was ready to be used with available plants inside, we needed to relocate to a different site, so the observation was halted. 


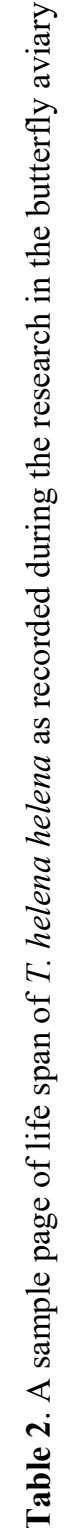

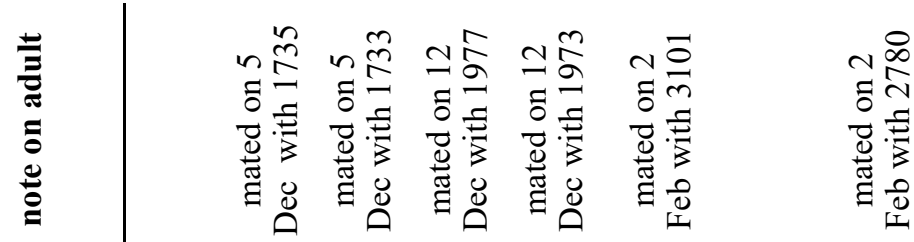

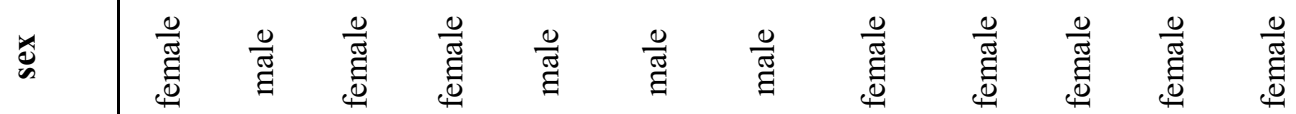

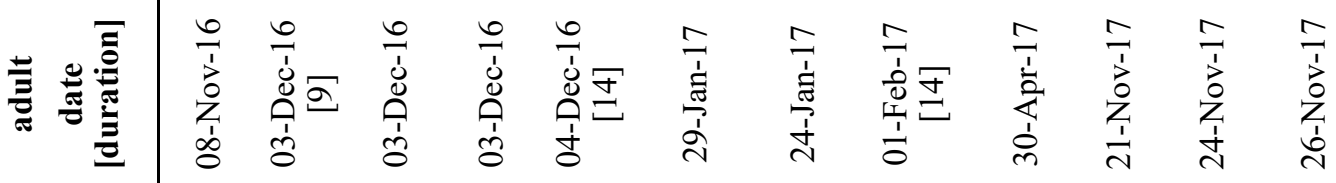

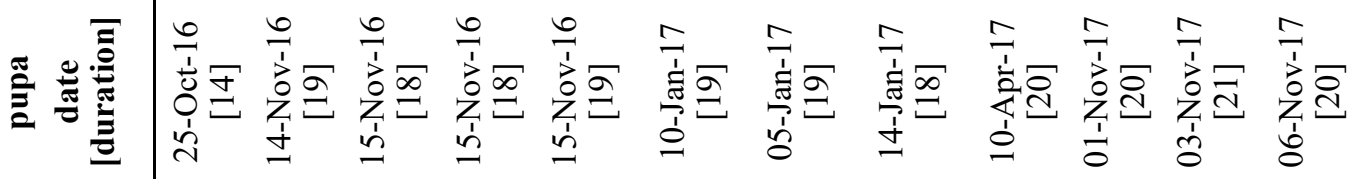

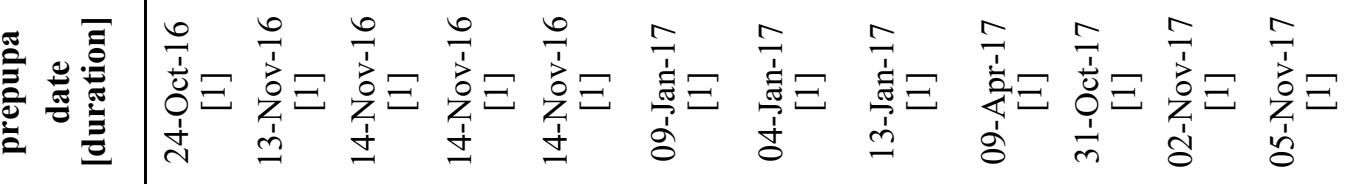

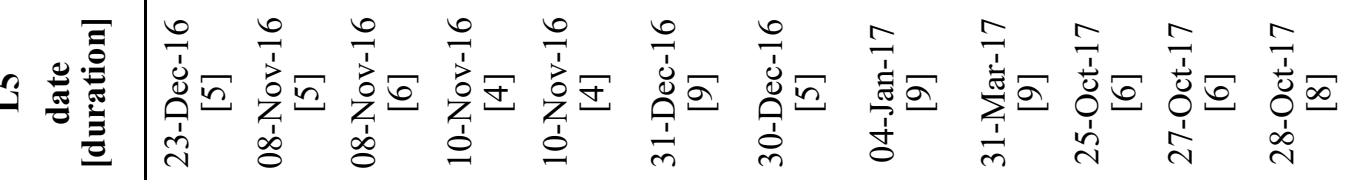

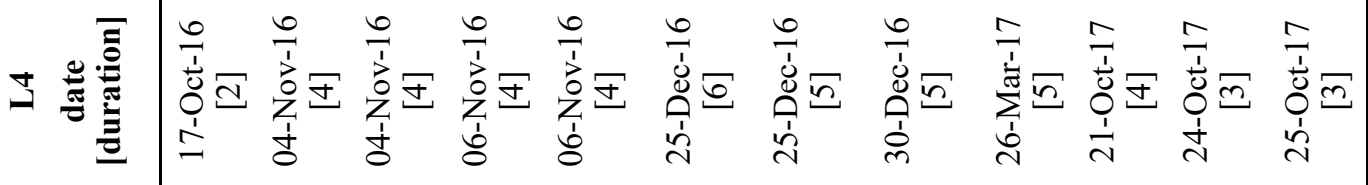

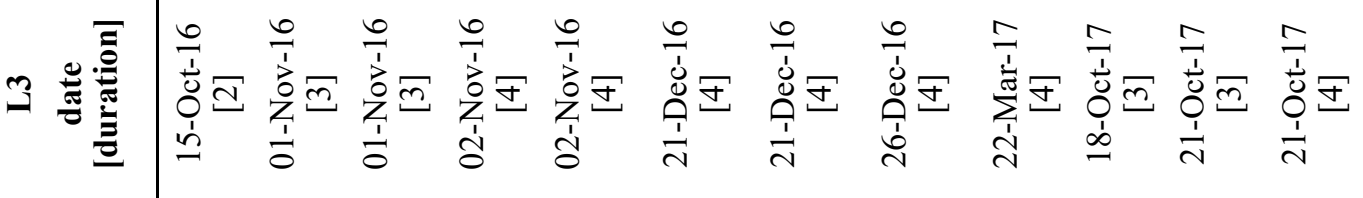

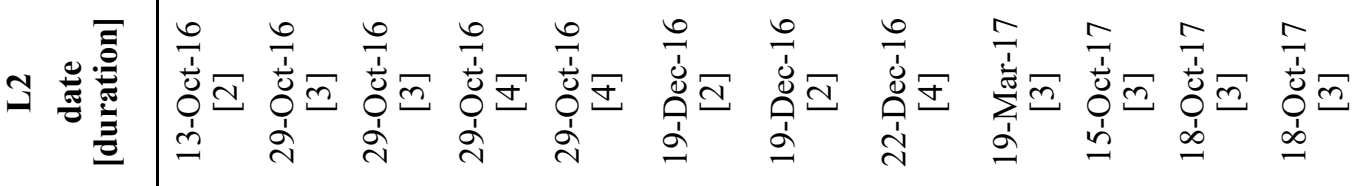

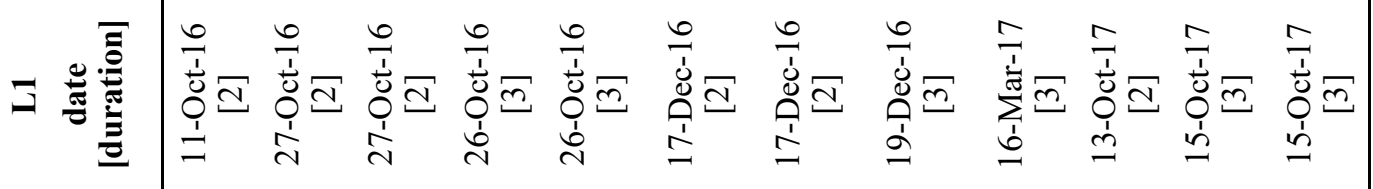

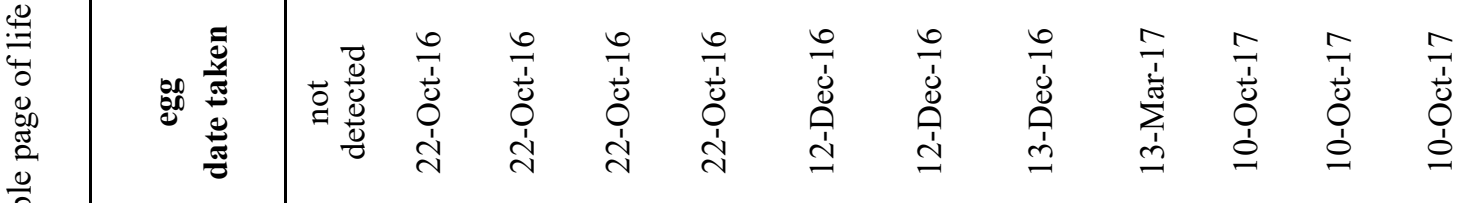

:

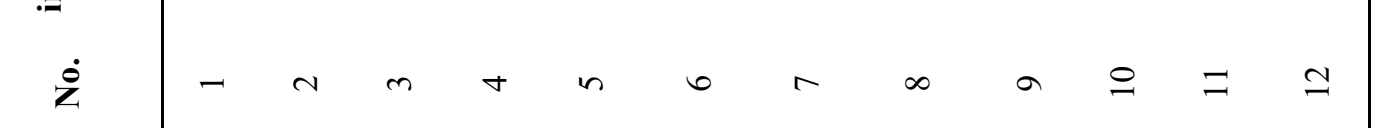


Peggie et al.: Can Troides helena and Pachliopta adamas co-exist? ....

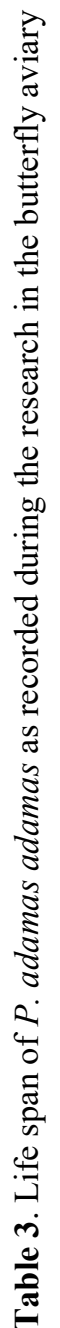

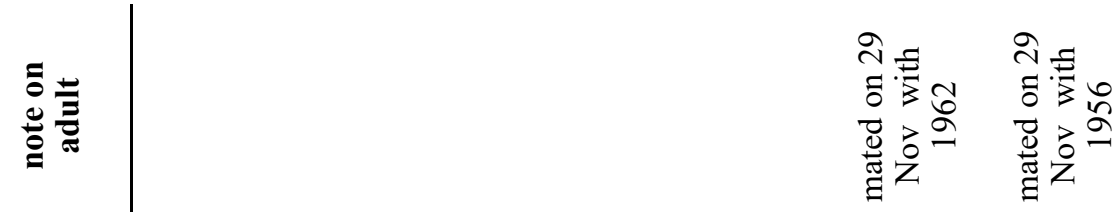

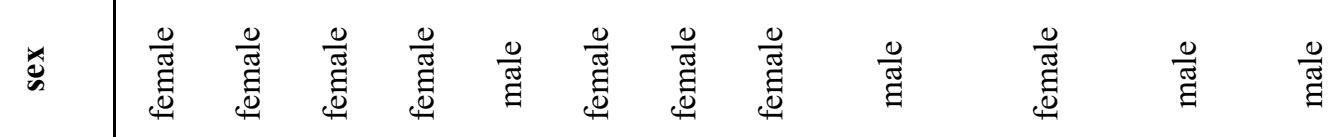

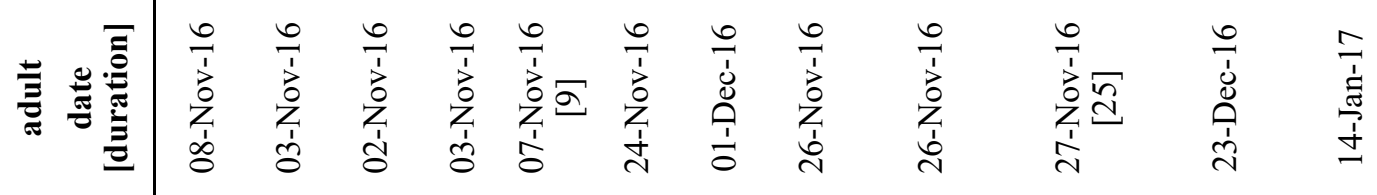

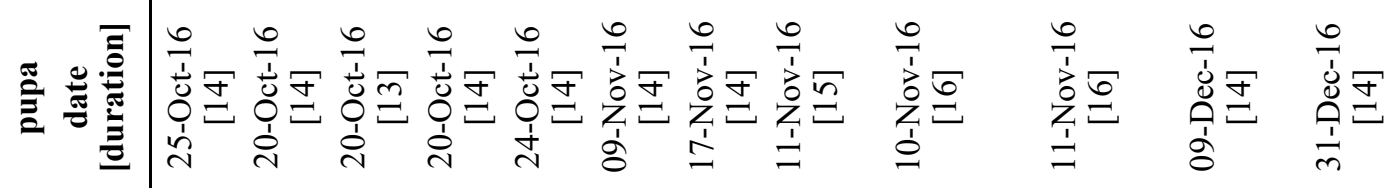

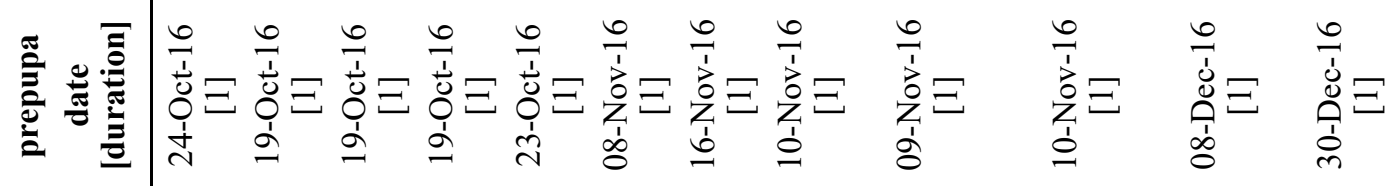

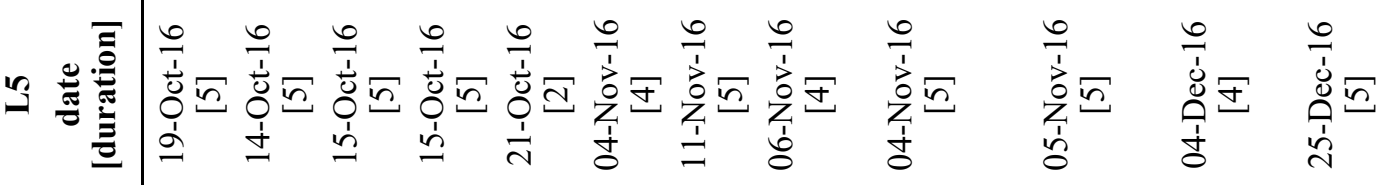

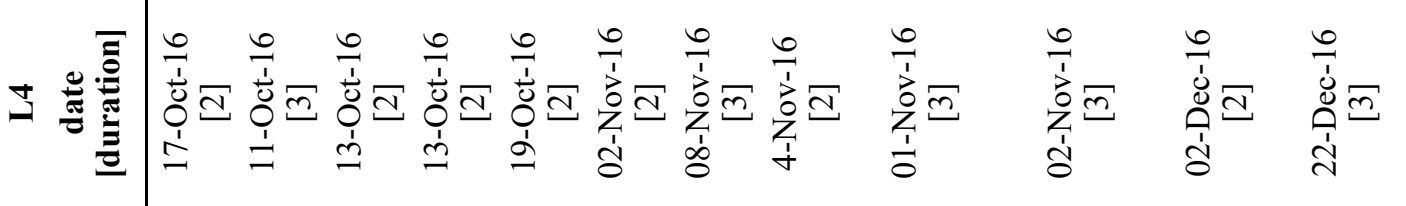

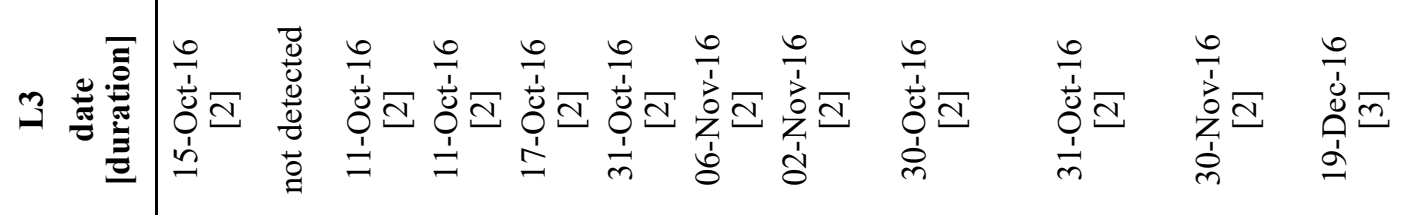

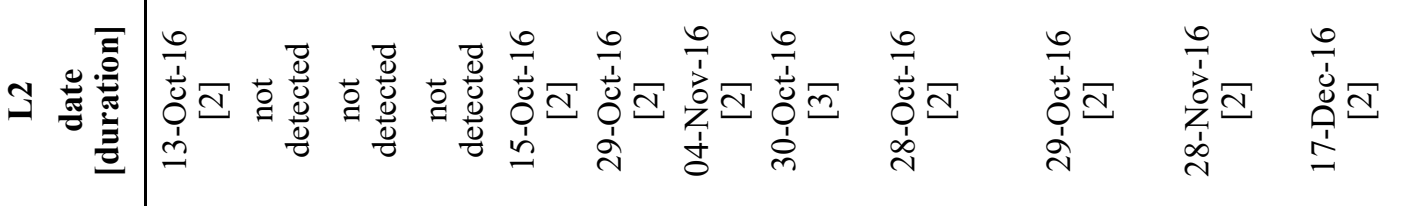

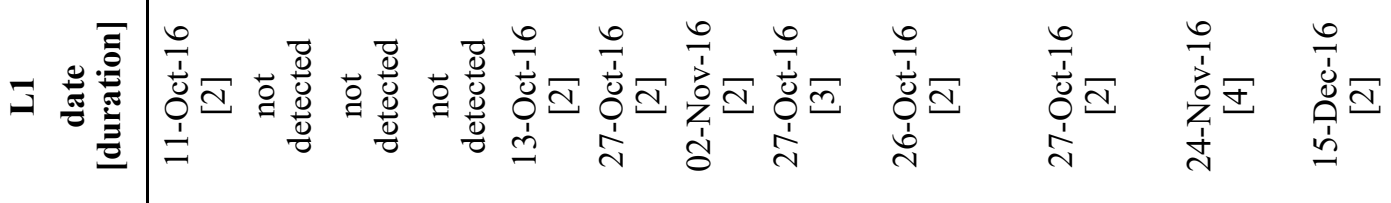

\begin{tabular}{l|llllllllllll}
0 \\
0 \\
0 \\
0
\end{tabular}

:

$\dot{\dot{z}} \mid-d \quad r \quad$

in 6 
Table 4. Observations on mating individuals of T. helena helena and additional information of the individuals

\begin{tabular}{|c|c|c|c|c|c|}
\hline No. & $\begin{array}{l}\text { individual } \\
\text { number }\end{array}$ & $\begin{array}{c}\text { date of } \\
\text { emergence }\end{array}$ & $\mathbf{M} / \mathbf{F}$ & observed mating & $\begin{array}{l}\text { adult life } \\
\text { span (days) }\end{array}$ \\
\hline 1 & 1733 & 3 Dec 2016 & male & mated on 5 Dec 2016 ( 2 days old) with 1735 & 9 \\
\hline 2 & 1735 & 3 Dec 2016 & female & mated on 5 Dec 2016 (2 days old) with 1733 & \\
\hline 3 & 1973 & 3 Dec 2016 & female & mated on 12 Dec 2016 (9 days old) with 1977 & \\
\hline 4 & 1977 & 4 Dec 2016 & male & mated on 12 Dec 2016 (8 days old) with 1973 & 14 \\
\hline 5 & 2759 & 27 Jan 2017 & male & mated on 3 Feb 2017 (7 days old) with 2816 & \\
\hline 6 & 2816 & 31 Jan 2017 & female & mated on 3 Feb 2017 (3 days old) with 2759 & \\
\hline 7 & 3012 & 27 Jan 2017 & male & $\begin{array}{l}\text { mated on } 6 \text { Feb } 2017 \text { (10 days) with } 3064 \text { and } \\
\text { were still mated at 16:15 }\end{array}$ & 18 \\
\hline 8 & 3064 & 30 Jan 2017 & female & $\begin{array}{l}\text { mated on } 6 \text { Feb } 2017 \text { ( } 7 \text { days) with } 3012 \text { and } \\
\text { were still mated at 16:15 }\end{array}$ & 15 \\
\hline 9 & 2780 & 29 Jan 2017 & male & mated 2 Feb 2017 (4 days) with 3101 & \\
\hline 10 & 3101 & 1 Feb 2017 & female & mated 2 Feb 2017 (1 day) with 2780 & 14 \\
\hline 11 & 3121 & 30 Jan 2017 & male & mated on 8 Feb 2017 (9 days) with 3135 & \\
\hline 12 & 3135 & 6 Feb 2017 & female & mated on 8 Feb 2017 (2 days) with 3121 & \\
\hline 13 & 6019 & 20 Oct 2017 & male & $\begin{array}{l}\text { mated on } 2 \text { Nov } 2017 \text { at 9:45 (13 days) with } \\
\text { newly emerged } 6119\end{array}$ & \\
\hline 14 & 6119 & 2 Nov 2017 & female & $\begin{array}{l}\text { mated on } 2 \text { Nov } 2017 \text { at 9:45 (newly } \\
\text { emerged) with } 6019\end{array}$ & \\
\hline
\end{tabular}
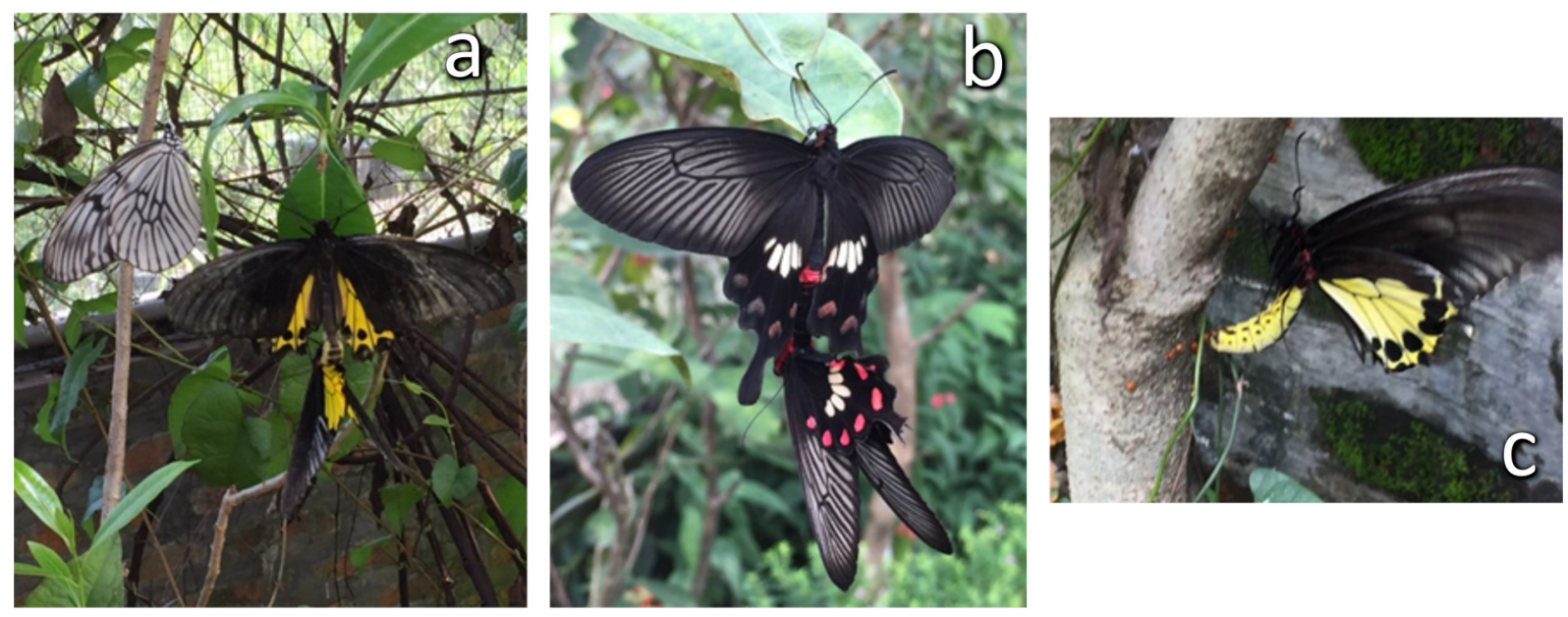

Figure 3. Observation in the aviary: (a) mating individuals of $T$. helena helena were noted, and another species: Idea blanchardii perched nearby; (b) mating individuals of P. adamas adamas were documented; (c) ovipositing female of $T$. helena helena on the branch of the host plants. 
There were many other butterfly species in the aviary at one time or another. However, they seemed to co-exist well. There were plenty of flowers that they could use for nectar. When flower supplies were not sufficient, we put sugar solution as an addition. Individuals of $T$. helena helena were often seen taking the $10 \%$ sugar solution that was placed on Hibiscus flowers.

\section{DISCUSSIONS}

This research demonstrates that planting host plants can encourage butterflies to come to the planting area and start the population at a new site (Neville, 1993; Peggie, 2019; Jain et al., 2021). The two species, being forest inhabitants (Igarashi \& Fukuda, 1997), have never been reported in the area prior to the establishment of the facility. However, four months after $A$. acuminata was planted, $P$. adamas adamas came to the area and laid eggs. About three weeks after that, individuals of $T$. helena helena were seen flying across and the female laid eggs. Apparently the butterfly species did notice the presence of the host plants and were attracted to come to the area. It is desirable to know the closest possible habitats of the species and do the mapping, preferably like that of Jain et al. (2021). But for now, we can only predict based on the association with the host plant. Because A. acuminata is a forest dweller, not an ornamental plant that regular household would have, possible habitats would be the Bogor Botanic Gardens (12.9 km away), or Sentul wooded areas (13.8 km away), or IPB campus (15.6 km away). Other smaller greeneries in the vicinity of our butterfly captive breeding facility are unlikely to be inhabited by both butterfly species without the presence of the host plants.

To know how well they could exist together in the captivity, our observation (Fig. 1) showed that at the beginning, in November 2016, P. adamas adamas male individuals were thriving but soon after male and female individuals of $T$. helena helena were released into the aviary, they started to decline in January 2017. Nonetheless, in March 2017 they seemed to co-exist quite well. The chart also showed that the trend of T. helena helena increased and decreased despite the low numbers of $P$. adamas adamas during many months. This indicates that the key factor to co-existence of both species seems to be the availability of sufficient host plants as also demonstrated by Curtis et al. (2015). We observed that both species did not chase each other away. Males of the same species were often seen approaching mating pairs, but the two species were never seen interacting negatively. However, larvae of $P$. adamas adamas often cut the lower stem of the host plants, to the extent that they would cause damage to the plants. This behavior needs attention for captive breeding operation. We would have had the opportunity to examine further if the facility was not relocated in October 2020. The plants including A. acuminata had grown so well in the area at the time of relocation and many of them did not survive the move. 
It is not the aim of this paper to cover the life history of both species in great detail. The life history of T. helena was available from previous studies such as Nurjannah (2010) and excellent work of Tan (2011). The life history of $P$. aristolochiae observed in Assam, India was presented by Barua \& Slowik (2007). We confirmed their findings of T. helena, but we found a slight deviation of the duration of each instar for early instar larvae and a quite large deviation of the duration of instar 4 and 5 (Table 2). The variations in the duration of early instars and late instars, understandably were due to the intensity of feeding activity. Some larvae spent 2 days as L1 and L2 but others spent 3 days. Also, as they matured to later instars, some would molt into the next instar in 3 days and others would take 4 or 5 days. The average duration spent as larvae was 20.8 days whether some started to grow faster at the beginning but usually they reached the pupation time at about the same. However, using only 10 individuals of $T$. helena helena reared at an IPB University's facility, about $15.6 \mathrm{~km}$ from our site, Nurjannah (2010) reported that the average duration taken as larval stage was 27 days, and it was 19 days for T. helena hephaestus, a Sulawesi subspecies. Our results on 71 individuals showed the average duration from eggs to adults was 45.9 days. Some eggs and larvae could not survive due to occasional attacks of parasitoids, as reported by Nacua et al. (2020), even within an enclosed environment. Nurjannah (2010) pointed out that species of Scelionidae (Hymenoptera) was a parasitoid of the eggs. A few pupae failed to eclose, and this could result from the poor development or possibly rough handling during their sensitive time of molting. Our observations indicated that they could endure some disturbances, except perhaps around their molting time. Most pupae of $T$. helena helena that were used for recording of pupal sound (Kurniati et al., 2018) successfully emerged as healthy individuals. Many adults could live well over 2-3 weeks, especially when they were eager eaters during larval stages.

As with $P$. adamas adamas, the larval stage consists of 5 instars and took 12.2 days on average. Barua \& Slowik (2007) reported 4 instars for the larvae of $P$. aristolochiae in India. The average duration from eggs to adults was 32.6 days. Some adults could live over 2 weeks and some individuals were recorded still alive for 25 days.

The determination of the adult life span was obtained through finding broken wings and recording the activity of adults. Many individuals might live longer but we could not determine with certainty if we could not find the wings or took photos of them while they were still flying. This was quite challenging as they were usually on high places that we could not see the marks given on the wings indicating the number of the individual.

Observations on mating and egg laying behaviors were conducted whenever we saw the opportunities. Data presented on Table 4 showed that a newly emerged female (\#6119) was approached and mated with a male (\#6019) of 13 days old. This observation showed that a 
female can mate on the day of its emergence and that individuals can still mate at older age. The copulation also lasts for a long time, as we documented many pairs that were still in copulation until late in the afternoon.

Butterflies of both species would go to most flowers for nectars. Corbet (2000) and Tiple et al. (2009) pointed out that butterflies can use almost any flowers that can be reached by the proboscis (Corbet, 2000; Tiple et al., 2009). Even when there were so many other butterfly species inside the aviary, individuals of $T$. helena helena were also seen taking sugar solution that was placed on Hibiscus flowers on plastic trays.

Within three years (October 2016-September 2019), we observed a total of 1,361 individuals of the two species. As many as 700 individuals of T. helena helena, and 348 of $P$. adamas adamas eclosed successfully into imago, and they had been marvelous sights in the aviary and outside. The research was quite satisfying and we appreciated the lessons learned from the obstacles to improve the conditions.

\section{CONCLUSION}

This research has given some insights into the knowledge of both species for maintaining a sustainable captive breeding program. Habitat enrichment by planting the host plants can encourage butterflies to come and populate the area. When food plants are sufficient, T. helena and P. adamas can co-exist at the facility. Data on the duration of the life cycle of $T$. helena helena and of $P$. adamas adamas were presented.

\section{ACKNOWLEDGMENTS}

This research was supported by Biovillage program 2016-2017 coordinated by Research Center for Biotechnology-Indonesian Institute of Sciences (LIPI) and Biovillage program 2018 coordinated by Research Center for Biology-Indonesian Institute of Sciences (LIPI) through Indonesian government project DIPA 2016-2018. We thank the reviewers who kindly read and improved the manuscript.

\section{REFERENCES}

Barua, K.K. \& Slowik, J. 2007. Study on the biology and consumption potential of Common Rose Pachliopta aristolochiae aristolochiae F. (Lepidoptera: Papilionidae) on Aristolochia tagala. Polish Journal of Entomology. Polskie Pismo Entomologiczne, 76: 341-352.

Corbet, S.A. 2000. Butterfly nectaring flowers: butterfly morphology and flower form. Entomologia Experimentalis et Applicata, 96: 289-298.

Curtis, R.J., Brereton, T.M., Dennis, R.L.H., Carbone, C. \& Isaac, N.J.B. 2015. Butterfly abundance is determined by food availability and is mediated by species traits. Journal of Applied Ecology, 52(6): 16761684. 10.1111/1365-2664.12523 
Endo, T. \& Ueda, K. 2004. A Complete Guide to the Endangered Swallowtail Butterflies of the World. Japan: Tokyo: Endless Science Information: $100 \mathrm{pp}$.

Hagler, J.R. \& Jackson, C.G. 2001. Methods for marking insects: Current techniques and future prospects. Annual Review of Entomology, 46: 511-543.

Igarashi, S. \& Fukuda, H. 1997. The Life Histories of Asian Butterflies. Vol. 1. Japan: Tokyo: Tokai University Press: 543 pp.

Jain A., Zeng, Y. \& Webb, E.L. 2021. Critical dependence of butterflies on a non-native host plant in the urban tropics. Frontiers in Ecology and Evolution, 9: 655012. doi: 10.3389/fevo.2021.655012

KLHK. 2018. Peraturan Menteri Lingkungan Hidup dan Kehutanan Republik Indonesia, Nomor P.106/ MENLHK/setjen/Kum.1/12/2018. tentang perubahan kedua atas Peraturan Menteri LHK Nomor P.20/ MENLHK/setjen/Kum.1/6/2018 tentang jenis tumbuhan dan satwa yang dilindungi.

Kurniati, H., Peggie, D. \& Sulistyadi, E. 2018. Pupal acoustic behaviour of Troides helena helena (Linnaeus, 1758) (Lepidoptera: Papilionidae) from West Java, Indonesia [Tingkah laku suara pupa Troides helena helena (Linnaeus, 1758) (Lepidoptera: Papilionidae) dari Jawa Barat, Indonesia]. Jurnal Biologi Indonesia, 14(10): $1-10$.

Nacua, A.E., Clemente, K.J., Macalalad, E.P., Galvez, M.C., Belo, L.P., Orbecido, A.H., Custer C. \& Deocaris, C.C. 2020. Butterflies behaviors and their natural enemies and predators in Manila, Philippines. Asian Journal of Conservation Biology, 9(2): 240-245.

Neville, D. 1993. Butterfly farming as a conservation tool, Lessons learnt during implementation of butterfly farming in the Arfak Mountains, Irian Jaya. Presented at the International Butterfly Conference, Ujung Pandang, pp. 24-27.

New, T.R., Pyle, R.M., Thomas, J.A., Thomas, C.D. \& Hammond, P.C. 1995. Butterfly conservation management. Annual Review of Entomology, 40: 57-83. https://doi.org/10.1146/annurev.en. 40.010195.000421

Nurjannah, S.T. 2010. Biologi Troides helena helena dan Troides helena hephaestus (Papilionidae) di Penangkaran. Thesis. Sekolah Pasca Sarjana Institut Pertanian Bogor, 101 hal.

Page, M.G.P. \& Treadaway, C.G. 1995. Revision of the clasification of Pachliopta aristolochiae (Fabricius, 1775) (Lepidoptera: Papilionidae) with special reference to the Philippine Islands. Beiträge zur Kenntnis der Lepidopteren der Philippinen, II. Contributions to the knowledge of the Lepidoptera of the Philippines, II. Nachrichten des Entomologischen Vereins Apollo, Suppl. 14: 125-148.

Peggie, D. 2011. Precious and Protected Indonesian Butterflies. Bogor: Nagao NEF \& Pusat Penelitian Biologi: $72 \mathrm{pp}$.

Peggie, D. 2018. Kajian diversitas kupu-kupu (Lepidoptera: Papilionoidea \& Hesperioidea) dan potensi pemanfaatannya di Hutan Petungkriyono, Kabupaten Pekalongan, Jawa Tengah. Jurnal Kajen, 2(2): 105122.

Peggie, D. 2019. Biological aspects of Papilio peranthus (Lepidoptera: Papilionidae) as observed at Butterfly Research Facility - LIPI, Cibinong, Indonesia. Treubia, 46: 85-102.

Tan, H. 2011. Life history of the Common Birdwing (Troides helena cerberus). Butterflies of Singapore. Retrieved October 20, 2021, from https://butterflycircle.blogspot.com/2011/08/life-history-of-commonbirdwing.html

Tiple, A.D., Khurad, A.M. \& Dennis, R.L.H. 2009. Adult butterfly feeding-nectar flower associations: constraints of taxonomic affiliation, butterfly, and nectar flower morphology. Journal of Natural History, 43 (13): 855-884. DOI: 10.1080/00222930802610568.

Tsukada, E. \& Nishiyama, Y. 1982. Butterflies of the South East Asian Islands. Vol. I. Papilionidae. Plapac Co., Ltd., Tokyo, Japan, pp. 340-342.

Veenakumari, K. \& Mohanraj, P. 1994. Life history of Pachliopta rhodifer (Papilionidae: Troidini). Journal of the Lepidopterists' Society, 48(2): 111-120.

Yao, T.L. 2015. Flora of Peninsular Malaysia: Aristolochiaceae. Seed Plants, 5: 5-46. 